\title{
Haçlı Devletlerinde (Outremer) Kullanılan Unvanlara Dair
}

\section{About the Titles Used in The Crusader States (Outremer)}

\author{
Ebru Altan* (D)
}

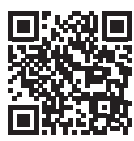

"Prof. Dr., İstanbul Üniversitesi, Edebiyat Fakültesi, Tarih Bölümü, İstanbul, Türkiye

\section{ORCID: E.A. 0000-0003-4246-7672}

Sorumlu yazar/Corresponding author: Ebru Altan,

İstanbul Üniversitesi, Edebiyat Fakültesi, Tarih Bölümü, İstanbul, Türkiye

E-posta/E-mail: efaaltan@yahoo.com

Başvuru/Submitted: 27.05.2020 Revizyon Talebi/Revision Requested: 22.06.2020

Son Revizyon/Last Revision Received: 26.06.2020

Kabul/Accepted: 26.06 .2020

\section{Atıf/Citation:}

Altan, Ebru. "Haçlı Devletlerinde (Outremer) Kullanılan Unvanlara Dair." Tarih Dergisi - Turkish Journal of History, 71 (2020): 67-81. https://doi.org/10.26650/TurkJHist.2020.005

\section{öz}

Birinci Haçlı Seferi (1096-1099) sırasında ve sonrasında Doğu'da Latinler tarafından kurulmuş olan ve outremer şeklinde ifade edilen dört Haçlı Devleti, hükümdarın taşıdığı hâkimiyet unvanına bağlı olarak kralık, kontluk, prinkepslik gibi farklı isimlerle anılmıştı. Kudüs'ün ilk Latin hükümdarı taçlandırılmadığı için yaygın olarak prinkeps unvanını kullanmış; fakat 1100 yılından itibaren krallığın hükümdarları resmen kral sıfatını taşımışlardır. Feodal bir yapıya sahip olan bu Latin devletlerinde kralın vasalları olan iktâ sahibi asiller lord, senyör, baron gibi farklı unvanlarla tanımlanmıştır. Bu devletlerin en önemli idarî birimlerinde yer alan seneşal, konnetabl, marşal, çemberlayn ve şansölye olarak adlandırılan yüksek memurların unvanları da kendi içinde hiyerarşik bir sıraya sahip olmuştur. Bu yazıda Kudüs Krallığı, Urfa Kontluğu, Trablus Kontluğu ve Antakya Prinkespliği olarak adlandırılan Haçlı Devletlerinde kullanılmış olan hâkimiyet ile asalet ve memuriyet unvanları kaynakların verdiği bilgiler ışığında ele alınmıştır.

Anahtar sözcükler: Haçlı Devletleri, Outremer, unvan, asalet, memuriyet

\section{ABSTRACT}

The four major Crusader States (Outremer), founded in the East by the Latins due to the First Crusade, were called a kingdom, county or principality depending on their ruler's title. The first ruler of the Crusader Kingdom adopted the title of princeps instead of king. Officially, from the the year 1100 , rulers of the Kingdom carried the title of king. In these Latin States with a feudal structure, the nobles who were vasals of the king were designated as lord, seigneur or baron. Also, high officers in the most important administrative units of the Outremer were called seneşal, konnetabl, marşal, çemberlayn and şansölye in a hierarchical order. This paper examines the titles of sovereignty, nobility and office holder used in the Crusader States of the Kingdom of Jerusalem, the Principality of Antioch, the County of Edesa and the County of Tripoli.

Keywords: Crudaser States, Outremer, title, nobility, official 
XI-XII. yüzyıllarda Güneydoğu Anadolu, Suriye ve Filistin'de Latinler tarafindan kurulan ve Haçlı Devletleri (Outremer, deniz aşırı ülke) olarak adlandırılan siyasî teşekküllerin idarî yapıları birbirine benzer olsa da bu devletler, hükümdarın taşıdığı hâkimiyet unvanına bağlı olarak krallık, kontluk, prinkepslik gibi farklı isimlerle anılmışlardır. Bunun yanında, günümüzde feodalizm olarak adlandırılan sisteme benzer bir idarî yapıya sahip olan söz konusu Latin (Frank) devletlerinde kralın doğrudan vasalları olan asillerin taşıdığı sıfatlar ile yüksek memuriyet unvanları da kendi içinde hiyerarşik bir sıraya sahipti. Bu yazıda Birinci Haçlı Seferi sayesinde Doğu'da kurulan Haçlı Devletlerinde kullanılmış olan hâkimiyet, asalet ve memuriyet unvanları ele alınacaktır.

\section{Kudüs'ün İlk Latin Hükümdarı Godefroi'nın Unvanları (Prinkeps, Advocatus)}

Kudüs'ün Latinler tarafından işgalinin (15 Temmuz 1099) ardından burada kurulan idarî sistem başlangıçta oldukça karışık bir durum arz ettiği için bu devletin ilk Haçlı hükümdarının kullanacağı unvan tartışma konusu olmuştu' ${ }^{1}$. Bazı liderler Tanrı 'nın Krallı̆̆ $ı$ olarak addedilen bu topraklarda doğrudan papa tarafından idare edilecek teokratik bir sistem düşünmüşlerdi. Fakat devlet, teokratik değil monarşik bir krallık şeklinde gelişme gösterecek, papalık da bunu takip eden süreçte Haçlı Devletlerinin hamisi olmaya devam edecektir.

Filistin'de Hz. İsa'nın mirası olarak görülen krallığga (regnum) ${ }^{2}$ bir hükümdar (rex) seçmek için 17 Temmuz 1099'da yapılan toplantıda, özellikle din adamları Hz. İsa'nın acı çektiği, dikenli taç giydiği bu topraklara bir kral seçilmesinin doğru olmadığını ileri sürüp bunun yerine Tanrı'nın Krallı̆̆ı'nı (Regnum Dei) koruyacak bir savunucu (advocatus) seçilmesini istemişlerdi. Bu yüzden Toulouse Kontu Raymond de St. Gilles kendisine krallık teklif edilince Kudüs'e, İsa'nın Krallı̆̆ı'na, bir kral seçme fikrinin günahkârlık olacağı düşüncesiyle bu unvanı kabul edemeyeceğini belirtti. Bunun üzerine 22 Temmuz'da yapılan toplantıda Aşağı Lorraine Dükü Godefroi de Bouillon Kudüs'ün ilk hükümdarı seçildi; ama bu tartışmalı unvanı almaktan çekinerek kral olarak taçlandırılmayı kabul etmedi. Bu yüzden taçlandırılmadığı için kral unvanını taşımasa da resmen bir krallığın hükümdarı olmuştu. Runciman $^{3}$ gibi bazı tarihçiler Godefroi’nın, dindarlığı sebebiyle Kudüs’te kilisenin yüksek hâkimiyetini kabul ettiği için kral unvanını almadığını düşünürler; ama onun bu noktada politik davranıp din adamlarıyla çatışmaktan veya kiliseyle yetki konusunda karşı karşıya

1 Papanın Haçlı ordusundaki temsilcisi, Le Puy Piskoposu Adhemar bir süre önce ölmüştü. Yeni Papalık Legatı Daimbert ise ancak Eylül 1099'da Doğu'ya ulaşacaktı.

2 Papa II. Urbanus, 1095 yılında Clermont'ta Haçlı Seferi çağrısı yaparken herkesi Tanrı'nın Krallı̆̆ı'nı kurtaracak bir sefere davet etmişti, Fulcherius Carnotensis, Gesta Francorum Iherusalem Peregrinantium, RHC occ., III, Paris 1866, s. 324.

3 St. Runciman, Haçlı Seferleri Tarihi, I, terc. F. Işıltan, Ankara 1989, s. 226. 
gelmekten kaçınmış olması mümkündür ${ }^{4}$. Öte yandan Ortaçağ politik anlayışına göre meşru bir kral olabilmek için papa veya imparator gibi evrensel bir gücün bu konuda yetki vermesi hususunda bir gereklilik de söz konusuydu5.

Godefroi de Bouillon (1099-1100) Kudüs Krallığı'na hükümdar seçildikten sonra, kaynaklarda Avrupa'da kullandığı dük unvanının yanı sıra daha çok prinkeps olarak anılmıştır (dux et princeps Ierusalem, princeps regni veya prinkeps civitati). O, ismen kral olmasa da Tanrı'nın Krallığı'nın, Haçlı liderleri tarafından yapılan bir seçim yoluyla Tanrı tarafından belirlenmiş hükümdarı olarak görülmüştü. Godefroi, prinkeps unvanının yanı sıra kaynaklarda “Kutsal Mezar’ın Savunucusu” (Advocatus Sancti Sepulchri) olarak da tanımlanmıştır6.

Prinkeps: Latince kökenli princeps kelimesi "birinci, önde gelen, hükümdar" gibi anlamları ifade ediyordu. Avrupa'da hanedanın erkek üyelerine verilen bir soyluluk unvanı olan prens kelimesi de bu kökenden türemiştir. Fakat günümüzde de kullanılan prens tabiri ile prinkeps kelimesinin tamamen aynı anlamı ifade ettiğini söylemek doğru olmaz. Bu tabir, Roma imparatorlarının resmî unvanı olarak, "eşitler arasında birinci” (primus inter pares) anlamında, ilk kez İmparator Augustus (M.Ö. 27- M.S. 19) tarafından kullanılmıştı. Roma tarihinde Augustus ve Diokletianus'un (285-305) saltanatı arasında kalan ve kendilerini princeps olarak adlandıran imparatorların dönemi de principat (principatus, imparatorluk) olarak anılmıştır ${ }^{7}$. Zaman içinde değişime uğrayan prinkeps terimi, Haçlı Seferleri döneminde, belirli bir bölgede tam tasarruf hakkına sahip bağımsız bir toprak sahibi için kullanılırdı. Bununla beraber Birinci Haçlı Seferi’nin çağdaş kaynakları bu sefere kumanda eden liderleri tanımlarken de sık sık adı geçen terimi kullanmışlardır ${ }^{8}$. Ayrıca Haçlı ordusunda yer alan diğer

4 Gesta Francorum, nșr. ve trc. R. Hill, The Deeds of the Franks and the Other Pilgrims to Jerusalem, Oxford 1979, s. 92 vd; Raimundus Aguilers, Historia Francorum qui ceperunt Jerusalem, RHC occ., III, Paris 1866 s. 295 vd., 301 / trc. H. Hill-L. Hill, Raymond d'Aguilers, Historia Francorum Philadelphia 1968, s. 121 vd., 129; Fulcherius, RHC occ., III, s. 361; Lignages d'Outremer, RHC Louis, II, s. 441; J. Riley-Smith, "The Title of Godfrey of Bouillon", Bulletin of the Institute of Historical Research, 52 (1979), s. 83-86. Haçl1 Seferi'ne katılmamıș olup XII. yüzyılın ilk yarısında seferin görgü tanığı anonim bir müellife ait olan Gesta Francorum'u temel alarak Kuzey Fransa'da I. Haçlı Seferi tarihini yeniden yazan Guibertus, Baldericus, Robertus adlı üç keşiş (E. Altan, Antakya Haçlı Prinkepsliği Tarihi, Ankara 2018, s. xvı11) tarafından kaleme alınan eserlerde Godefroi kral (rex) olarak zikredilmiștir. Bkz. Robert the Monk's History of the First Crusade, Historia Iherosolimitana, trc. C. Sweetenham, Aldershot 2005, s. 202; A.V. Murray, The Crusader Kingdom of Jerusalem: A Dynastic History, 1099-1125, Oxford, 2000, s. 69 vd.

5 R. Hiestand, "Some Reflections on the Impact of the Papacy on the Crusader States and the Military Orders in the Twelfth and Thirteenth Centuries", The Crusades and the Military Orders, ed. Z. Hunyadi -J. Laszovsky, Budapest 2001, s. 10 vd.

6 Gesta Francorum, s. 92; Fulcherius, RHC occ., III, s. 361; Albertus Aquensis, Liber Christianae Expeditionis, nşr. ve trc. S. B. Edgington, Albert of Aachen. Historia Ierosolimitana, History of the Journey to Jerusalem, Oxford 2007, VII, 30; Murray, s. 70.

7 Princeps ve principatus terimleri hakkında bkz. J. F. Niermeyer, Mediae latinitatis Lexicon Minus, Leiden, 1976, s. 849-51.

8 Bkz. Gesta Francorum, s. 13, 36, 93, Fulcherius, RHC occ., III, s. 245vd., 332, 348, 357; Raimundus, $R H C$ occ., III, s. 267. Ordunun liderleri için prinkeps yerine bazen maiores veya seniores gibi terimler de kullanılmıştır (Gesta Francorum, s. 18, 30, 35). Birinci Haçlı Seferi ordularında prinkeps unvanının kullanımı hakkında geniş bilgi için bkz. C. Kostick, The Social Structure of the First Crusade, Leiden, 2008, s. 213-241. 
seçkin asiller için de bu sıfat (principes noblissimi) söz konusu olmuştur. Bu sebeple liderleri, diğer önde gelen asillerden ayırt etmek için prinkeps unvanı genelde büyük anlamında başka sıfatlarla beraber (principes maiores) kendini göstermiştir?'

Böylece genelde hem Haçlı Seferi'nin liderleri hem de ordudaki diğer önde gelen asiller için prinkeps unvanı kullanıldığından Godefroi, Kudüs hükümdarı olunca üstünlügü vurgulanarak “Kudüs'ün en yüce prinkepsi” (summus princeps Ierusalem) olarak tanımlanmıştır'10. Onun kardeşi Baudouin de Boulugne, Urfa'ya geldikten sonra (Şubat 1098) prinkeps (principe Baldwino, princeps Balduinus $)^{11}$ sıfatıyla tanımlanmış; daha sonra Kudüs'te taçlandırıldıktan (11 Kasım 1100) sonra da kral unvanının yanı sıra bazen yine princeps (magnificus princeps) şeklinde anılmıştır ${ }^{12}$.

Bundan başka Norman lider Bohemud Antakya'da, yeğeni Tankred ise Galilaea'da hâkimiyet kurduktan sonra bağımsız olduklarını vurgulamak için bu unvanı kullanmışlardı. Güney İtalya'da önce Lombard liderler tarafından kullanılan bu unvanı daha sonra adı geçen bölgeyi işgal eden ve papalıktan başka hiçbir yüksek hâkimiyeti tanımayan Norman reisleri de kullanmıştı. Bu sebeple Antakya'nın zaptından sonra burada hâkimiyet kuran Bohemund, kendi bölgesinde tüm otoriteyi elinde bulunduran bağımsız bir hükümdar olduğunu, Batı Avrupa'da veya Yakındoğu'da herhangi bir hükümdarın yüksek hâkimiyeti altında bulunmadığını gösterecek şekilde prinkeps unvanını (princeps Antiochie) benimsemişti. Bu sebeple buradaki Haçlı Devleti literatürde küçük bir egemen devlet anlamında genellikle prinkepslik (principat, principatus) olarak anılmıştır ${ }^{13}$.

Advocatus (savunucu): Godefroi, Kudüs hükümdarı olarak prinkeps unvanını benimserken "Kutsal Mezar'ın Savunucusu" (Advocatus Sancti Sepulchri) olarak da anılmıştı. Bazı tarihçilere göre bu unvan, onun kilisenin hâkimiyetini kabul ettiğini ve yetkisinin kilise adına mukaddes yerlerin savunulmasıyla sınırlı olduğunu göstermiştir ${ }^{14}$. Papa II. Urbanus vefatından kısa süre önce (29 Temmuz 1099) Pisa Piskoposu Daimbert'i legatlık yetkisi ve önemli bir deniz gücüyle beraber Doğu'ya göndermişti. Godefroi’nın hükümdar seçilmesinden bir süre sonra (Eylül 1099) Laodikeia’ya ulaşan Daimbert, buradan Antakya Prinkepsi Bohemund ve Urfa Kontu I. Baudouin ile birlikte Kudüs’e gitmişti (21 Aralık). Ardından Arnulf’un azlini takiben Kudüs patriği seçilmiş (1 Ağustos) ve 1099

9 Raimundus, RHC occ., III, s. 272. Kaynaklarda bazen Musul Valisi Kürboğa, Danişmedli Gümüştegin Gazi gibi Müslüman lider ve hükümdarlar da princeps olarak adlandırılmıştır, bkz. Albertus, 1v, 12, v11, 27.

10 Albertus, v1, 48. Bazen de magnificus princeps: Albertus, v11, 30; v1, 37.

11 Albertus, 111, 17; 1v, 6. Baudouin 1100 yılında Kudüs kralı olunca Urfa’yı kendisine iktâ ettiği akrabası II. Baudouin de prinkeps olarak adlandırılmıştır (princeps Rohas veya principis Rohas civitatis, Albertus, 1x, 40; X11, 31).

12 Fucherius, RHC occ., III, s. 367; Albertus, v11, 42; Willermus, RHC occ., III, s. 387; Kostick, s. 228.

13 Albertus, v, 26; Willermus, RHC occ., III, s. 755; Altan, Antakya, s. 99.

14 J .L. La Monte, Feudal Monarchy in the Latin Kingdom of Jerusalem, 1100 to 1291, Cambridge 1932; Runciman, I, s. 226; J. Prawer, The Crusaders'Kingdom, London 2001, s. 37. 
yılındaki Noelde Kudüs'te Godefroi, Antakya'da Bohemund'un hâkimiyetini törenle tasdik etmişti ${ }^{15}$. Her ne kadar Godefroi, 120 gemiden oluşan Pisa filosunun desteğini alabilmek için daha sonra patriğe bazı tavizler vermek zorunda kalsa da bu üç lider kendilerini onun vasalı olarak görmemişlerdi. Ama Daimbert, başında patriğin bulunduğu teokratik bir sistem hususundaki arzusunu açıkça ifade etmiş ve bu konuda çaba göstermiştir. Anlaşılan, prinkeps unvanı Godefroi'nın kiliseye tâbi bir görevli olmaktan ziyade gerçek manada bir hükümdar olduğunu ortaya koymaktadır. Bu durumda hükümdarlık unvanı princeps olan Godefroi’nın advocatus olarak da anılması aslında kilisenin ve Hıristiyan toplumun müdafaası hususundaki sorumluluğuna işaret etmektedir. Bütün Hıristiyan hükümdarlar Latin Kilisesi'ni korumakla görevliydiler; özellikle Alman imparatorları, taçlandırma merasimi sırasında Roma Kilisesi'nin koruyucu ve savunucusu olacaklarına dair yemin ederlerdi. Roma geleneğinde advocatus (veya defensor, savunucu) kelimesi imparator, kral ve prinkeps unvanlariyla birlikte sıkça kullanılmışt1 ${ }^{16}$.

Bununla beraber Godefroi'nın kendisinin advocatus unvanını nadiren kullandığ anlaş1lıyor. Papa II. Urbanus'un halefine hitaben Eylül-Ekim 1099'da Laodikeia'da (Lâzikiye) yazılan bir mektupta bu unvana rastlanır. Papalık legatı olarak Doğu'ya gönderilen Daimbert Laodikeia'ya ulaştı̆̆ında orada bulunan Toulouse Kontu Raymond de St. Gilles ile beraber bu mektubu yazmış ve o sırada Kudüs'te olan Godefroi'nın adı da mektuba dâhil edilmişti; ama bu onun imzasını taşıyan resmî bir belge değildii ${ }^{17}$. Bununla beraber, Godefroi ve Baudouin'in Haçlı Seferi hakkında bilgi veren ve seferden geri dönenlerden aldığı bilgileri de kullanarak XII. yüzyılın ortalarına doğru Laurence de Liège tarafından yazılmış olan Gesta episcoporum Virdunensium adlı eserde Godefroi'nın Kudüs Krallı̆̆ı'na hükümdar seçildiği; fakat onun kral olarak değil advocatus olarak anıldığ1 görülmüştür ${ }^{18}$. Sadece Godefroi değil onun haleflerinin de bu tür koruma ve savunma anlamı içeren unvanlar kullandığı anlaşılmaktadır. Nitekim Godefroi’nın halefleri I. Baudouin (1100-1118), II. Baudouin (1118-1131) ve I. Amaury (1162-1174), kral (rex) unvanlarının yanı sira "Kutsal Mezar ve Kudüs'ün savunucusu", "Hristiyanlığın savunucusu", defensor ve advacatus gibi unvanlarla anılmışlardır. Sonuçta Kudüs’te dini olmayan bir monarşinin temelleri atılırken krallığın idaresi ve Hıristiyan toplumun savunulup korunması görevini üstlenmiş olan Godefroi, hâkimiyet yetkisinin doğrudan Tanrı'dan alınmış olduğunu vurgulayacak şekilde prinkeps unvanını, kiliseye karşı sorumluluğunu göstermesi açısından da "savunucu" (advocatus) unvanını benimsemiştir ${ }^{19}$.

15 Albertus, v11, 6-7; Wilermus, RHC occ., III, s. 385-387 / terc. Krey, I. s. 400-403.

16 Riley-Smith, "The Title of Godfrey of Bouillon”, s. 86; Murray, s. 75vd.

17 Riley-Smith, "The Title of Godfrey of Bouillon", s. 83.

18 Bkz. Murray, s. $71 \mathrm{vd.}$

19 Murray, s. 73, 77. 


\section{Kral (rex) Unvanının Kullanılması ve Kralın Yetkileri}

1100 yılında Godefroi’nın vâris bırakmadan ölümü üzerine Filistin'e davet edilen kardeşi Urfa Kontu I. Baudouin, dünyevi bir monarşiyi savunuyor, ama krallıktaki en yüksek dinî otorite tarafından tanınmayı da önemsiyordu. Bu durum, kendisine yarı ilahi bir güç kazandıracak olan krallık yetkisini doğrudan Tanrı'dan aldığının somut ve resmî bir göstergesi olacaktı. Öte yandan kral unvanı hem Galilaea bölgesinde prinkeps unvanıyla bağımsız bir hükümdar gibi davranan ve Patrik Daimbert'in müttefiki olan Norman lider Tankred'e karşı kendisine bir üstünlük getirecek, hem de kiliseden bağımsız bir hükümdar olduğunu ortaya koyacaktı. Sonunda Baudouin de Boulogne, bazı itirazlara rağmen 1100 yılının Noelinde Bethlehem Kilisesi'nde yapılan törenle Patrik Daimbert tarafından taçlandırılarak resmen kral unvanını aldı. Bunu takiben Kudüs kralları kaynaklarda Jerusalem Latinorum rex olarak tanımlanmışlardır ${ }^{20}$.

Kral I. Baudouin(1100-1118), bazı çağdaş Avrupa monarşilerinin aksine yetkileri merkezde toplamak yerine asilleriyle paylaştı. Kral devletin en yüksek ve itibarlı mevkiinde bulunsa da yetkileri sınırsız değildi; yasama ve yargı güçlerini elinde bulunduran ve asillerden oluşan bir feodal konsil vard1: Yüce Divan (Haute Cour bazen curia generalis, curia regis) "En Yüksek Anayasa Mahkemesi" veya "Yüksek Adalet Divanı" olarak krallıktaki en etkili kurumdu. Kudüs krallık tahtı bazen seçimle bazen de intikal yoluyla elde edilebiliyordu. Asiller ve piskoposların devletin başı olarak seçtiği kralın konsil tarafından onaylanması ve tanınması gerektiğinden seçimden sonra konsilde yapılan bir törenle resmen görevine başlardı. $\mathrm{Bu}$ toplantıda konsil üyeleri yeni krala hizmet ve sadakat yemini ederlerdi. Böylece Yüce Divan tarafından tanınmış olan kral, eşitler arasında birinci (primus inter pares) addedilirdi. Kral, yüksek divanın başkanı, ordunun başkumandanı ve merkezi idarenin sorumlusuydu. Yüksek memurları atar, vasallarına iktâ edilen toprakların satılmasına veya başkasına devredilmesine mani olabilir, dul kalan vârislere koca seçebilirdi. Bunun dışında Yüce Divan bir hukuk ve yargı kurulu olarak toplanacak vergilerden, askerî seferlerin onaylanmasına, para basma vs. işlerine kadar her konuya müdâhildi. Danışma meclisi gibi krala tavsiyeler verir, bazen görüş ayrılığı yüzünden kralla anlaşmazlığa düşebilirdi. Haute cour ayrıca cinayet, ihanet ve kölelerin serbest bırakılması, dirliklerin satılması, feodal anlaşmazlıklar gibi ceza davalarıyla da ilgilenirdi. Fakat asil olmayan Frank vatandaşlarının davalarına büyük şehirlerdeki "Burjuva Mahkemeleri" (bourgeois, vatandaş) bakardı; bu mahkemenin başkanı ise şehrin viskontu (reis) idi²1.

Kont ve Haçlı Kontlukları: Latince comes (refakatçi, gözetmen) kelimesinden gelen kont terimi, Roma İmparatorluğu zamanında saraydaki bazı ileri gelen memurlara, yüksek

20 Fulcerius, RHC occ., III, s. 382; Albertus, v11, 43; Murray, s. 95 vd.

21 La Monte, s. 87-106; Runciman, II, s. 250 vd.; Işın Demirkent, “Kudüs Krallığg’nda Devlet İdaresi”, Haçll Seferleri Tarihi, Makaleler-Bildiriler-İncelemeler, İstanbul 2007, s. 249-255. 
mevki sahibi kişilere verilen onur unvanıydı. Roma idarî geleneğini büyük ölçüde devam ettiren Frank Devleti'nde (Merovenjiyen - Karolenjiyen) en yüksek memurların yanı sıra yerel komutan ve yargıç gibi yüksek mertebedeki görevlilere de bu unvan verildi. Fakat ilk Frank kralları zamanında bazı kontların belirli bir görevi yoktu; bunlar krala bağlı olarak onun emirlerini yerine getiren kimselerdi. Bu unvanın ifade ettiği anlam X. yüzyıldan XII. yüzyıla kadar bir hayli değişiklik gösterdi. Feodal gelişmeyle beraber seçkin bir kraliyet memuru olmaktan çıkan kont, kendisine veraset yoluyla intikal eden sınırlı bir bölgede vasal statüsünde hüküm süren bir kişiydi. Fakat, toplumda ayrı bir sosyal sınıf olan ve aristokrasiyi oluşturan lordlardan bazıları, bu sınıfa dâhil olmakla beraber kendilerine intikal eden bir kontluğa sahip olmasalar da kont unvanını aldılar. XII. yüzyılda orta statüdeki bir lord, kont unvanını alabilirdi'22.

Urfa ve Trablus'da kurulan Haçlı Devletlerinin ${ }^{23}$ hükümdarları kont unvanıyla anılmışlardı. Urfa Kontluğu'nun kurucusu olan Baudouin de Boulogne, ailesinden kendisine toprak mirası kalmadığı için dini mesleğe yönelmiş olsa da Haçlı Seferi’nden bir süre önce şövalye olmak için kiliseden ayrılmış ve ağabeyi Godefroi de Bouillon'un hizmetine girmişti ${ }^{24}$. Bu dönemde en geç 1096 yılında Godefroi'nın Lorraine'deki (Lotharingia) vârisi olarak tanınmış olan Baudouin, ayrıca Verdun Piskoposluk bölgesine ${ }^{25}$ ait olan toprakların kontu seçilmişti. Godefroi de Bouillon Haçlı Seferi'ne çıkmadan önce kendi kontrolündeki Verdun Kontluğu'nu Piskopos Richer'e teslim etmişti. Bunun üzerine, bölgesindeki kontu tayin etme hakkına sahip olan piskopos da Verdun Kontu unvanını Baudouin'e vermişti. Fakat Baudouin kısa bir süre sonra ağabeyi ile birlikte Doğu'ya sefere gitmeye karar vererek kontluğu piskoposa teslim etti. Çünkü Godefroi Haçlı Seferi için para sağlamak amaciyla Lorraine bölgesindeki topraklarını satmış veya ipotek ettirmişti. Bu durumda başka dayanağı kalmayan Baudouin, piskoposluk bölgesinin kontu olarak bağımsız hareket etme firsatı bulamazdı. I. Baudouin Mart 1098'de Urfa'da hükümdar olduktan sonra da kont unvanını benimsemişti ${ }^{26}$.

Trablus Haçlı Kontluğu'nun temellerini atan Birinci Haçlı Seferi liderlerinden Toulouse Kontu Raymond de St. Gilles'in Doğu'daki halefleri de onunla aynı unvanı taşımış ve 1109'da kurulan devlet kontluk olarak anılmıştır. Fakat Antakya Prinkepsliği gibi, bu iki

\section{Niermeyer, s. 204-206.}

23 Latince Comitatus Edessanus ve Comitatus Tripolitanus şeklinde anılan Urfa Kontlu ile Trablus Kontluğu, Willermus, RHC occ., III, s. 755; Jacques de Vitry, "Historia Iherosolimitana", Gesta Dei per Francos, ed. J. Bongars, I/2, Hanoviae, 1611, p. 1068-1069.

24 Işın Demirkent, Urfa Haçlı Kontluğu Tarihi (1098-1118), TTK-Ankara 1990, s. 1 vd.

25 Verdun Piskoposu Haimont (990-1024) ve haleflerine kont unvanı bağlı oldukları Kutsal Roma Germen İmparatoru III. Otto tarafindan (996-1002) verilmişti.

26 Murray, s. 34 vd. Haçlı Seferi sırasında Baudouin'in ordusunda vaiz olarak yer alan ve kontluğun kuruluş aşamasına şahit olan Fulcherius (RHC occ., III, s. 367, 374) efendisini lord (dominus) ve kont (comitis Balduini) olarak tanımlamış̧ır. Baudouin Urfa'ya hâkim olduktan sonra dük (dux) unvanıyla da zikredilmiştir (Baldwinus dux civitatis Rohas, Albertus, VII, 31, 33). 
kontluk da doğrudan doğruya Kudüs Krallığg’na bağlı değildi; aslında toprakları teorik olarak da krallığın bir parçası sayılmıyordu; daha ziyade kralının üstünlüğünü tanıyan müttefik devletler statüsündeydiler. Kudüs kralı, Doğu'daki bütün Frank Devletlerinin yüksek hâkimi olarak görülse de Kudüs’te ancak kudretli bir şahsiyet hüküm sürdüğü zaman kontlara bunu fiilen (de facto) kabul ettirebilmişti; yani bu kontlarla Kudüs kralları arasında ilişkilerde daha ziyade kişisel anlaşmalar veya bağlar belirleyici olmuştu. Krallığın ilk dönemlerinde kontlar krala sadakat yeminiyle biat ederek onun yüksek hâkimiyetini tanımışlardı, ama bu üstünlük kralın unvanından dolayı değil şahsi gücünden kaynaklanmıştı. Kral, bu Haçlı Devletlerini Müslümanlar veya Bizans tarafından bir dış tehdit söz konusu olduğunda koruyan, liderler arasındaki anlaşmazlıklarda arabuluculuk yapan üstün bir konumdaydı. Ayrıca krallar, Doğu'daki Latin hükümdarlardan birinin esareti sırasında ya da çocuk yaşta olması sebebiyle baronların daveti üzerine nâip sıfatıyla devletin sorumluluğunu üstlenmiş, vasilik yapmış veya genç vâriselerin evlendirilmesi gibi bazı yetkileri de kullanmıştır. Urfa ve Trablus Haçlı kontları dış işlerinde bağımsız olup savaş, barış ve anlaşma yaparken kralın rızasını almak zorunda değillerdi; ama savaş zamanında kralla iş birliği içinde olurlardı. Mesela Trablus Kontu III. Raymond (1152-1187), Hıttin Savaşı (1187) öncesinde Selâhaddin Eyyûbî ile barış yapmış olduğu halde kralla beraber adı geçen savaşta yerini almıştı.

Kudüs Krallığı'ndan daha önce kurulmuş bağımsız bir devlet olan Urfa Kontluğu'nun ilk hükümdarı I. Baudouin (1098-1100), ağabeyi Godefroi’nin halefi olmak üzere Filistin'e giderken akrabası II. Baudouin du Bourg'u vasalı sıfatıyla Urfa'nın idaresiyle görevlendirmişti (1100). Aynı şekilde daha sonra II. Baudouin Kudüs kralı olurken (1118) Urfa'yı kendisine vasallık yemini eden Joscelin de Courtenay’e iktâ etmişti. Kudüs'ün ilk kralları Trablus üzerinde de yüksek hâkimiyet kurmuşlardı. 1109 yılında Trablus ele geçirildiğinde Raymond de St. Gilles'in oğlu Kont Betrand, Kral I. Baudouin'e vasallık yemini ederek Trablus'un hâkimi olmuştu; fakat Bizans İmparatoru Aleksios Komnenos (1081-1118) ile de şahsen müttefikti. Daha sonra Trablus Kontu Pons, 1122 önce Kral II. Baudouin'e, 1131 yilında da Kral Foulque'a karşı vasallık statüsünü terk etmeye kalkışsa da ilkinde kendi divanının zoruyla, ikincisinde de mağlup olarak tekrar Kudüs kralına itaat arz etmek zorunda kalmışt1 ${ }^{27}$. Kral Amaury ise 1164-1171 yılları arasında çocuk yaştaki Trablus Kontu III. Raymond'un en yakın erkek akrabası olarak niyabetini üstlenmişti. Fakat III. Raymond büyüyünce kralın yüksek hâkimiyetini kabul etmedi, üstelik eşinden dolayı Galilaea Prinkepsi unvanını da taşıyordu.

Antakya Prinkespi Bohemund (1098-1111) ve halefleri ise hiçbir zaman Kudüs kralını metbu olarak görmemişlerdi. Fakat Kudüs kralları metbu sıfatıyla olmasa da gerektiği zaman yüksek divanın kararıyla Antakya'da nâiblik görevini üstlenmişlerdi. Nitekim Kral II. Baudouin (1100-1118), Roger de Salerne'in 1119 y1lında Artuklu İlgazi (1106-1122) ile

27 Bkz. Fulcherius, III, 11; Willermus, XII, 17; XIV, 4-5. 
yapılan Kanlı Meydan Savaşı'da hayatını kaybetmesi üzerine ülkenin güvenliği söz konusu olduğundan Antakya'daki baronların davetiyle niyâbet görevini üstlenmişti. 1126 yılında prinkespliğin meşru vârisi II. Bohemund Doğu'ya gelince de devleti ona teslim etmişti. Ancak kızı Alice ile evlendirdiği II. Bohemund, kısa süre sonra Kilikya'da Danişmendiler ile savaşta ölünce (1130) kral, bu kez torunu küçük Prenses Constance'ın vasisi olarak baronların daveti üzerine bir kez daha aynı görevi üstlenmişti ${ }^{28}$.

\section{Asalet Unvanları: Lord, Senyör, Baron}

XII. yüzyılda Kudüs Krallı̆̆ı, Batı Avrupa'daki çağdaş birçok devlet gibi, asiller tarafından idare edilen çok sayıda yarı bağımsız bölgeden oluşmaktaydı. Latinler tarafından Doğu'da kurulan idarî yap1, Ortaçağ Avrupa'sındaki düzenin benzeri olmakla beraber elbette farklılıklar arz ediyordu ${ }^{29}$. Ülkenin Tanrı'ya ait olduğu ve kralın onun arzusuyla hüküm sürdüğü anlayışının hâkim olduğu sistemde kral piramidin en üstünde yer alsa da kiliseye karşı sorumluydu. İlk 30 yıl içinde Müslüman hâkimiyetindeki şehirlerin ve kalelerin ele geçirilmesiyle krallığın hâkimiyet alanı genişledi ve asillere arazi tahsis etme uygulaması başladı. Bu asiller, krala vergi ödemenin yanı sıra askerî hizmet şartıyla kendilerine tahsis edilen bölgelerde hüküm sürebiliyorlardı. Toprak; sahibi öldüğünde, Filistin'den ayrıldığında ya da sahip olduğu mülkünü, arazisini satmak zorunda kaldığında el değiştirebilirdi. Ayrıca veraset hakkını elinde bulunduran kral herhangi bir sebeple bu toprağın devlete iadesini isteyebilirdi. Dirlik sahibi ağır bir suç işlerse mahkeme kararıyla da toprağı elinden alınabilirdi.

I. Baudouin 1118 yılında öldüğünde Tyrus (Sûr) ve Askalan dişında bütün sahil şehirleri Frankların hâkimiyetine girmişti. Asalet sınıfının önde gelen mensuplarına başlıca kentler veya topraklar tahsis edilmiş ve sistem içinde zamanla bir hiyerarşi oluşmuştu. Doğu'daki feodal sistemde bu bölgeler genel olarak lordluk, senyörlük veya baronluk unvanıyla anılıyordu. Sadakat yemini ederek krala tâbi olan ve askerî hizmet karşılığında kendilerine fief (feudum, iktâ) tahsis edilmiş olan asiller ${ }^{30}$, doğrudan kralın vasallarıydı. Bu feodal beyler kaynaklarda lord, senyör, baron, kont, princeps gibi unvanlarla zikredilmişlerdir. Bunların hizmetinde olan daha aşağı derecedeki asiller de dolaylı olarak kralın vasalı sayılıyordu. Şövalyeler ise toprak sahiplerinin emrindeki soylu ve eğitimli askerlerdi. Doğu'da krallar sadece önde gelen asillere değil askerî hizmet karşılığında şövalyelere de araziler tahsis ederlerdi; ama şövalyelerin büyük kısmına bazı şehir ve köylerden sağlanan para-iktâları

28 Kudüs kralının Urfa, Trablus ve Antakya'nın Haçlı hükümdarlarıyla ilişkisi ve hukuki durumu hakkında geniş bilgi için, bkz. T.A. Archer-C.L. Kigsford, The Crusades, The Story of the Latin Kingdom of Jerusalems, New York 1902, s. 115 vd.; La Monte, s. 187- 202; Runciman, II, s. 254 vd.

29 Filistin'deki Feodalizm hakkında bkz. J. Riley-Smith, The Feudal Nobility and The Kingdom of Jerusalem, 1174-1277, London 1974, s. 3-20. La Monte, (s. 87), bunu "ideal feodal sistem" olarak açıklamıştır.

30 Latin kaynaklarında yüksek asalet sınıfı genellikle şövalyelerden (milites) ayrı tutulur ve principes, proceres veya optimates olarak tanımlanır (Albertus: milites et principes regni Iherusalem). 
verilirdi. Şövalyeler, kralın vasalleri veya lordların vasalleri olabilirdi; ikinci durumda ise kralın dolaylı vasalları sayılıyorlardı.

Lord (dominus): Latince "efendi, sahip, hâkim, hükümdar" anlamlarını taşıyan bir unvandı. Senyör, baron gibi unvanlardan birini taşıyan iktâ sahibi soylu bir vasal, aynı zamanda lord olarak anılır; hükümdarın vasalı olarak üzerinde hüküm sürdüğü topraklar da lordluk (dominium) unvanını taşırdı.

Senyör (seigneur, bey, efendi): Ortaçağda toprak sahibi feodal lordlara (beylere) verilen bir soyluluk unvanı olup bir senyörün üzerinde hüküm sürdüğü toprak senyörlük olarak tanımlanırdı. Bu unvan Latin Doğu'da yaygın olarak kullanılmış, bu feodal beyler baron olarak da anılmıştır.

Baronlar (baron, çoğul: barones): Kudüs’teki iktâ sahipleri arasında "yüksek sınıf, zengin adamlar veya baronlar" denilen bir grup vardı. Latince baro (adam) kelimesinden gelen bu terim, kaynaklarda açıkça tanımlanmasa da söz konusu dönemde genellikle büyük vasallar ve ülkenin önde gelen şahsiyetlerinden oluşan seçkin bir grubu ifade etmek için kullanılmıştı; ama büyük iktâ sahibi vasalların yanı sıra daha mütevazi iktâların sahiplerinin de baron olarak anıldığı olmuştur ${ }^{31}$. XIII. yüzyıl ortalarında Filistin'deki en büyük hukuk bilginlerinden biri olan Yafa-Askalan Kontu Jean d'Ibelin'in (1215-1266) ifadesine göre, genel olarak doğrudan krallığa bağlı dört büyük vasallık baronluk olarak tanımlanmıştır: Yafa ve Askalan Kontluğu; Galilaea Prinkespliği; Maverai-Ürdün Senyörlüğü; Sidon (Sayda) Senyörlüğü. Bu büyük baronlukların diğer lordluklardan ayrı tutulduğu, konstable ve marşal gibi yüksek derecedeki memurlarını kendilerinin belirlediği ve krallığın Yüce Divan'ına katılabildikleri anlaşılmaktadır. Galilaea Prinkepsi ve Yafa Kontu dışındaki bütün iktâ sahibi vasallar senyör, lord (dominus) olarak anılmışlardır ${ }^{32}$.

Bohemund'un yeğeni Tankred, yukarıda belirtildiği gibi, Birinci Haçlı Seferi sırasında Galilaea bölgesinde hâkim olduğu topraklarda bağımsızlığını ilan etmek için prinkeps unvanı alarak Galilaea (veya Taberiye) Prinkepsliği’ni kurmuştu. Godefroi tarafindan Geldemar Carpenel'e vaat edilmiş olan Hayfa ele geçirilince (25 Temmuz 1100) patriğin de desteğiyle Tankred şehre hâkim olmuş, böylece toprakları Galilaea'dan sahile kadar genişlemişti. Fakat Bohemund'un 1100 yılında Danişmendlilere esir düşmesi üzerine nâip sıfatıyla Antakya'nın idaresini üstlenmek için Filistin'den ayrılırken (Mart 1101), bir yıl üç ay içinde geri dönmezse bu topraklardaki hâkimiyet hakkından vazgeçeceğine dair Kral I. Baudouin'e söz vermişti. Neticede Bohemund ancak Mayıs 1103'te esaretten kurtulabildiği için Tankred bu süre içinde geri dönemeyince toprakları krala devredilmişti. Bunu takiben Hugue de St. Omer kral

31 Niermeyer, s. 85 vd.; Riley-Smith, The Feudal Nobility, s. 16-20

32 Archer-Kigsford, 116; Riley-Smith, The Feudal Nobility, s. 16 vd. Daron (Darum), Hebron (St. Abraham), Beysan, Nazareth, Arsûf, Kaysâriye (Caesarea), Nablus, Tyrus, Hayfa, Toron, Banyas, Scandelion, Beyrut, Lydda, Montgisard diğer önemli iktâlar (fief) arasındaydı. 
tarafından kendisine iktâ edilen Galilaea bölgesinin prinkepsi olmuştu. Böylece Kudüs'ün vasalı olarak prinkepslik adıyla anılmaya devam eden bu baronluğun kendi vasalları da olmuştur (Beyrut, Nazareth ve Hayfa) ${ }^{33}$. Haçlılar tarafından 1099 yılında ele geçirilen Yafa ise genellikle kraliyet ailesinin mensuplarından birine tahsis olunurdu. Remle ve Ibelin de Yafa kontunun vasallarıydı. 1153 yılında Askalan'ın ele geçirilmesinden sonra birleşik Yafa-Askalan Kontluğu olarak anıldı. Kraliçe Melisende (1134-1151) ile Kral Foulque’un (1131-143) ikinci oğlu olan I. Amaury, 1162 yılında Kudüs kralı olmadan önce Yafa ve Askalan kontuydu.

Mâverâ-i Ürdün Senyörlüğü (Outre-Jourdain, Ürdün Ötesi), Ürdün Nehri’nin doğusunda Ölü Deniz'in güneydoğusuna kadar Kerek ve Montreal (Şevbek) kalelerini de içine alan geniş, fakat sınırları tam olarak tanımlı olmayan bir bölgede II. Baudouin zamanında kurulmuştu. Mısır'dan Dımaşk’a ve Arabistan'a giden kervan yollarının üzerinde bulunan bölge ekonomik açıdan da krallık için oldukça önemliydi. 1177 yılında bölgenin vârisesi Etiennette de Mily ile evlenerek Ürdün ötesindeki bölgeye hâkim olan Renaud de Chatillon, bu senyörlüğün son hâkimi olmuş, ama kralın tâbisi değil bağımsız bir prinkeps gibi hareket etmişti. Nitekim Hıttîn Savaşı (1187) öncesinde Selâhaddin Eyyûbî ile yapılmış bir ateşkes anlaşmasını (1185) tanımayarak Kahire'den Dımaşk'a giden Müslüman kervanına saldırdığı zaman, Kral Guy de Lusignan'ın bütün ısrarlarına rağmen Müslümanlarla kendisinin anlaşma yapmadığını ileri sürüp barışın korunması için tazminat ödemeyi reddetmiştir ${ }^{34}$.

\section{Devlet Görevlilerinin Unvanları}

Latin Doğu'daki (outremer) yüksek memuriyet unvanları XI. yüzyıl Fransa'sından alınmıştı. Doğu'da bu mevkiler nadiren verasetle babadan oğula geçer, bir iktidarın süresi bitince yüksek memurlar değişebilirdi. Kudüs Krallı̆̆ı'nda bu yüksek mevkiler iktâ sahibi asiller arasından seçilirdi. Seneşal (seneschal), konnetabl (constable), marşal (marshal), çemberlayn (chamberlain), şansölye (chancellor) unvanlarını taşıyanlar krallıktaki en yüksek devlet memurlarıydı. Diğer Haçlı devletleri de kendi saraylarında büyük ölçüde bu modele göre organize olmuşlardı. Ayrıca tarikat şövalyelerinin ve patriğin olduğu gibi dört büyük baronluğun ve Kaysâriye hâkimlerinin de kendi yüksek memurları vardı.

Seneşal (seneschal): Kralın şahsi temsilcisi olarak en yüksek memur sayılan seneşal, teşrifat nazırıydı. Doğu'da bu unvana sahip olan kişi, Avrupa'daki mevkidaşının aksine hiçbir zaman büyük bir güce sahip olamamıştır. Taç giyme töreninde hükümdarın önünde asayı taşır, bunu takiben verilen ziyafette krala servis yapardı. Ayrıca kraliyetin bütün memurları ve hazine dairesi de ona bağlıydı. Bütün kale ve şatoları teftiş eder, garnizonları bir şatodan ötekine transfer edebilirdi; ancak şatoların valileri üzerinde yetkisi yoktu. Kral

33 Fulcerius, RHC occ., III, 384/ Ryan, s. 150 vd; Altan, Antakya, s. 106-113.

34 Ebru Altan, "Renaud De Châtillon: Antakya Prinkepsi (1153-1160), Mâverâ-İ Ürdün Senyörü (1177-1187)", Tarih Dergisi, Say1 55 (2012 / 1), İstanbul 2013, s. 1-30. 
veya temsilcisi (bailli, nâip, vekil) bulunmadığı zamanlarda davalara bakabilir, Yüce Divan'1 toplayabilirdi. Krala seferlerde refakat eder veya kralın katılmadığı seferde ordusuna komuta edebilirdi. Savaş kazanılınca kralın ganimet payını alır ve muhafaza ederdi.

Konnetabl (constable): Şeref payesi açısından seneşalın önceliği olsa da ikinci sıradaki konnetabl aslında daha önemli bir figürdü. Batı'daki uygulamada sıradan bir askerî memur olan konnetabl, Doğu'daki krallığın en önemli görevlisiydi. Ordunun başı ve en yüksek kumandan olarak askerin idare ve organizasyonundan sorumlu olup taç giyme merasiminde kral kiliseye giderken ve dönerken kraliyet sancağını taşır, atının yularını tutardı. Askerlerin savaşta düzenini sağlar, eğer kral veya bailli şahsen sefere katılmamışlarsa kralın bütün savaş yetkilerine sahip olarak orduya komuta ederdi. Konnetabl seferlerde aynı zamanda askerî hâkim olup bütün davalara bakard1. Kendilerine sodeers denen Frank asıllı ücretli askerler hukuken ona bağlı olup bu askerlerin ödemelerinin düzenli yapılmasını sağlardı. Parasını alamayan bir asker konnetabla müracaat eder, o da borçlu olan lorddan parayı alırdı. Borçlunun parası yoksa konnetabl onun mallarına el koyup satardı. Lord borcunu inkâr ederse de mesele mahkemeye intikal ederdi. Pek çok ünlü baron, Kudüs'te konnetabl olarak adından söz ettirmişti: Sayda Hâkimi Eustache Garnier, Galilaea Prinkepsi Guillume de Buris, Onfroi de Toron, Amaury de Lusignan, Balian d'Ibelin gibi.

Marşal (marshal): Konnetablın sorumluluklarını paylaşan yardımcısı ve temsilcisiydi. Kralın ve konnetablın sözcüsü gibi hareket ederek onların emirlerini orduya iletirler, savaşta kraliyet sancağını taşır, savaştan sonra yine konnetablın emriyle ganimetin paylaşılmasını sağlar, kralın payını seneşale teslim ederdi. Bundan başka tüm atların sorumluluğu kendisindeydi. Savaşlarda ölen veya sakatlanan atların yerine yenilerini temin etmek (restor) en önemli görevlerindendi. Savaştan önce şövalyelerin, askerlerin silah ve malzemelerini teftiş eder, gerekli bakım ve onarımı sağlar, eksiklerini giderirdi. Bu teftişte bütün atları inceler, değerlendirir ve listesini yapard1. Turkopol (Turcoples) denilen ve isim olarak Bizans’tan alınmış olan ücretli askerler de marşala bağlı olup emirleri ondan alırlardı. Bu askerler ülke içindeki yerli Hıristiyanlardan, sonradan Hıristiyan olanlardan veya melezler arasından seçilip askere alınarak yetiştirilen hafif teçhizatlı süvarilerdi ${ }^{35}$.

Çemberlayn (chamberlain): Hâcib veya saray nazırı olarak tanımlanan çemberlayn saray masraflarının idaresi ve kralın şahsi maliyesinden sorumluydu. Ayrıca taç giyme merasimi günü kralı tören için giydirir, kraliyet kılıcını taşıyarak resmî geçidin önünde yürürdü. Kilisede diğer memurlardan tacı, asayı ve diğer eşyayı alıp krala verirdi. Vasallar krala sadakat yemini ederken onlara nezaret eder ve yemin metnini okuturdu. Krala sadakat yemini eden bütün vasallar ona bir hediye verirlerdi. Dolayısıyla bu makamın geliri oldukça iyiydi.

35 Bizans ordusundaki Turkopoller, Türk asıllı ücretli askerdi (bkz. Y. Ayönü, "Bizans Ordusunda Ücretli Türk Askerler (XI-XII. Yüzylllar)”, Selçuk Üni.Türkiyat Araştırmaları Dergisi, 25 (2009), 64). Filistin'deki turcopoller hakkında bkz. La Monte, s. 160-162; Runciman, II, s. 244. 
Şansölye (chancellor): Hiyerarşide yüksek memuriyetlerin sonuncusu olan şansölye kraliyet sekreteri ve devlette yazı işlerinin başkanıydı. Bütün resmî evrakı kaleme alır, bunların kaydını tutar ve kralın mührünü bu evraklara basardı. Batı'daki gibi Kudüs'te de bu makamda daima bir din adamı bulunurdu; ama aynı zamanda saray papazı değildi. Şansölye, hiçbir zaman Batı'daki gibi yasama ve yargı gücüne sahip olmamış, her zaman kraliyet sekreteri olarak kalmıştır ${ }^{36}$.

Viskont: Krallığın yüksek memurlarından biri olmasa da mahalli idareden sorumlu önemli bir bölgesel memurdu. Kaynaklarda yetkisi konusunda çok detaylı bilgi mevcut değildir. Asillerden biri veya bir şövalye viskont seçilebilirdi. Kudüs Krallı̆̆ı'nda 37 kadar viskont görev yapardı. Bunlardan en önemli olanları Kudüs, Akka, Nablus (Neapolis) ve Daron'daki kraliyet viskontlarıydı. Kudüs Viskontluğu krallığın önemli bir idarî birimiydi. Bu dört viskontun haricindeki 33 viskont iktâ sahibi baronlar tarafından tayin edilirdi. Doğrudan krala bağlı şehirlerde kralın, iktâ arazilerinde ise o toprak sahibi olan lordun temsilcisi ve Burjuva Mahkemesi'nin reisiydi. Şehirdeki asayişin sağlanmasından sorumlu olup adli görevlerinin yanı sıra kendi bölgesindeki malî işlere de bakardı. Vergileri, kiraları, cezaları vs. toplar, mahalli idare için gerekli parayı ayırdıktan sonra kalanı hazineye teslim ederdi. Yerel idareci olarak viskont, yasakları ve fermanları çıkarır ve uyulmasını sağlardı. Sergeantlar da onun sorumluluğundaydı. Askerlikle yükümlü dirlik sahibi olan sergeantlar (sergent), büyük arazi sahiplerinin topraklarına yerleştirilmiş Frank asıllı ve askerlikle yükümlü tam teçhizatlı yaya askerlerdi.

Mathesep (muhtesib, çarşı pazarı denetleyen görevli): $\mathrm{Bu}$ Arapça unvan1 ${ }^{37}$ taşıyan görevli, viskontun vekili olup bazen baş sergeant olarak da anılmıştır. Sergeantları komuta eden mathesep, onların silah ve teçhizatından sorumluydu. Viskont ve mathesebe bağlı sergeant bölükleri güvenlik kuvveti olarak görev yaparlar, ayrıca çarşı ve pazarları denetlerdi. Bunların dışında butler (merasim görevlisi) dragomen (dragomannus, tercüman / Arapça konuşan kâtip), logothete, admiral gibi memuriyetler söz konusu olsa da bunlar hakkında kaynaklarda yeterli derecede mâlûmat mevcut değildir.

Kudüs Krallığı'ndaki baronlukların da kendi özel memurları vardı. Her büyük baronun kurşundan yapılmış mührü olurdu. Trablus Kontluğu'nda yüksek dereceli memurlar Kudüs’teki memurlarla aynı unvanları taşıyor ve aynı görevleri yapıyorlardı; şehirler de viskontlar tarafindan idare edilmekteydi. Antakya Prinkepsliği'nde seneşal, şansölye, konnetabl, marşal gibi yukarıda belirtilen memuriyetlerden başka dük $(d u x)$ olarak adlandırılan bir görevli daha vardı. Şehirlerin ve devlete bağlı arazilerin idaresi konusunda Bizans sistemini örnek alan Antakya Prinkepsliği'nde dükler Antakya, Lâzikiye ve Cebele'de idareden sorumlu kişilerdi.

36 Yüksek memurlar için bkz. Archer-Kingford, s. 124 vd.; La Monte, s. 116-123; Prawer, s. 123 vd.; Runciman, II, s. 253; Demirkent, “Kudüs Haçlı Krallı̆̆ı'nda devlet idaresi”, s. 256.

37 Muhtesib, İslâm devletlerinde kamu düzenini korumak ve denetlemekle görevli Hisbe teşkilâtının faaliyetlerinden sorumlu memur. C. Kallek, “Hisbe”, DIA, 18, s. 133-143. 
Bu görevliyi hükümdar tayin eder, istediği zaman da azlederdi. Antakya dükü Frank asiller arasından tayin edilirdi, ama yardımcısı viskont yerli memurlardan biri de olabilirdi. Lâzikiye ve Cebele dükleri ise çoğu zaman yerli halktan biri olurdu. Urfa Haçlı Kontluğu'nda ise şansölye, konstable ve marşaldan başka hazineden (secretarium) sorumlu olan bir secretarius (hazinedar) olduğu anlaşılmaktadır. Kontun bir vasallar divanı mevcuttu, ama büyük dirlik arazileri fazla değildi. Latinlerin en uçtaki ileri karakolu olan Urfa Kontluğu'nun yasal müesseseleri gelişmemiş olup memuriyetler de genelde Bizans sistemine göre yetişmiş olan Ermeni zümrenin elindeydi. Urfa'da idarî açıdan Bizans’tan kalan sistem devam ettirilmiş görünmektedir ${ }^{38}$.

Sonuç olarak, kaynakların verdiği bilgilerden anlaşıldığına göre, XII. yüzyılda Doğu'da biri krallık, biri prinkepslik, ikisi de kontluk olarak anılan dört büyük Haçlı Devleti kurulmuş, hükümdarın taşıdığı hâkimiyet unvanı devletin taşıdığı unvanın tanımlanmasında belirleyici olmuştur. Antakya Prinkepsliği ve bu iki kontluk doğrudan doğruya Kudüs Krallığı'na bağlı olmayıp daha ziyade kralın üstünlüğünü tanıyan müttefik devletler statüsündeydiler. Kudüs'ün ilk Haçı hükümdarı bazı itirazlar sebebiyle taçlandırılmadığı için hiçbir zaman kral unvanını taşımamış, prinkeps olarak ifade edilen hükümdarlık unvanını kullanmıştı. Fakat bunun yanı sıra kilisenin ve Hıristiyan toplumun müdafaası hususundaki sorumluluğuna işaret eden advocatus (Kutsal Mezar'ın Savunucusu) olarak da anılmıştı. 1100 yılından itibaren Kudüs hükümdarları resmen kral olarak taçlandırılmış ve bu unvanı kullanmaya başlamışlardır. Norman lider Bohemud da Antakya'ya hâkim olduktan sonra bağımsız olduğunu ilan etmek için prinkeps unvanını almış, Urfa ve Trablus’taki devletlerin hükümdarları ise kont unvanını taşımışlardır. Doğu'da ele geçirilen başlıca şehirler ve kaleler Asalet sınıfının önde gelen mensuplarına tahsis edilince feodal sistemde bu bölgelerin hâkimleri genel olarak lord, senyör veya baron unvanıyla anılmıştır. Fakat en büyük dört vasallık genelde baronluk olarak anılmak suretiyle diğer lordluklardan ayrı tutulmuştur. Bu devletlerde yükssek memurların taşıdığ1 unvanlar da hiyerarşik olarak seneşal, konnetabl, marşal, çemberlayn, şansölye olarak adlandırılmıştı. Bu unvanlar o dönemdeki Fransa'dan alınmış olsa da uygulamada konumu ve önemi her zaman aynı olmamıştır.

Hakem Değerlendirmesi: Dış bağımsız.

Çıkar Çatışması: Yazar çıkar çatışması bildirmemiştir.

Finansal Destek: Yazar bu çalışma için finansal destek almadığını beyan etmiştir.

Peer-review: Externally peer-reviewed.

Conflict of Interest: The author has no conflict of interest to declare.

Grant Support: The author declared that this study has received no financial support.

38 Archer-Kingsford, 125-127; La Monte, s. 135-137; Runciman, II, s. 254, 256; Riley-Smith, The Feudal Nobility, s. 86 vd., 89, 96; Demirkent, “Kudüs Haçlı Krallığı'nda devlet idaresi”, s. 257. 


\section{Kaynakça/References}

Albertus Aquensis, Liber Christianae Expeditionis pro Ereptione et Restitutione Sanctae Hierosolymitanae Ecclesiae, nşr. ve trc. S. B. Edgington, Albert of Aachen. Historia Ierosolimitana, History of the Journey to Jerusalem, Oxford 2007.

Ayönü, Yusuf, "Bizans Ordusunda Ücretli Türk Askerler (XI-XII. Yüzyıllar)”, Selçuk Üniversitesi Türkiyat Araştırmaları Dergisi, sayı 25 (2009), s. 53-69.

Demirkent, Işın, “Kudüs Krallığı'nda Devlet İdaresi”, Haçlı Seferleri Tarihi, Makaleler-Bildirilerİncelemeler, İstanbul 2007, s. 249-259.

, Urfa Haçlı Kontluğu Tarihi (1098-1118), TTK, Ankara 1990.

Fulcherius Carnotensis, Gesta Francorum Iherusalem Peregrinantium, RHC occ., III, Paris 1866, s. 311-485.

Gesta Francorum (Anonim), nşr. ve trc. R. Hill, The Deeds of the Franks and the Other Pilgrims to Jerusalem, Oxford 1979.

Hiestand, Rudolf, "Some Reflections on the Impact of the Papacy on the Crusader States and the Military Orders in the Twelfth and Thirteenth Centuries", The Crusades and the Military Orders: Expanding the Frontiers of Medieval Latin Christianity, ed. Z. Hunyadi -J. Laszovsky, Budapest 2001, s. 3-20.

Jacques de Vitry, "Historia Iherosolimitana", Gesta Dei per Francos, ed. J. Bongars, I/2, Hanoviae, 1611, s. 1051-1171.

Kallek, Cengiz, "Hisbe", DİA, c. XVIII, s. 133-143.

Kostick, Conor, The Social Structure of the First Crusade, Leiden 2008.

La Monte, John L., Feudal Monarchy in the Latin Kingdom of Jerusalem, 1100 to 1291, Cambridge 1932.

Lignages d'Outremer, RHC Louis, II, Paris 1843, s. 441-474.

Murray, Alan V, The Crusader Kingdom of Jerusalem: A Dynastic History, 1099-1125, Oxford 2000.

Niermeyer, J. F., Mediae Latinitatis Lexicon Minus, Leiden 1976.

Prawer, Joshua, The Crusaders Kingdom, London 2001.

Raimundus Aguilers, Historia Francorum qui ceperunt Jerusalem, RHC occ., III, Paris 1866, s. 231-309; trc. H. Hill-L. Hill, Raymond d'Aguilers, Historia Francorum qui ceperunt Iherusalem, Philadelphia 1968.

Riley-Smith, Jonathan, The Feudal Nobility and The Kingdom of Jerusalem, 1174-1277, London 1974.

Riley-Smith, Jonathan, "The Title of Godfrey of Bouillon", Bulletin of the Institute of Historical Research, 52 (1979), s. 83-86.

Robert the Monk's History of the First Crusade, Historia Iherosolimitana, trc. C. Sweetenham, Aldershot 2005.

Runciman, Steven, Haçlı Seferleri Tarihi, terc. F. Işıltan, I, Ankara 1989.

Willermus Tyrensis, Historia Rerum in Partibus Transmarinis Gestarum, RHC occ., I; terc. E. A. Babcock A. C. Krey, A History of Deeds Done Beyond the Sea. By William Archbishop of Tyre, I, New York 1943. 
